\title{
Viral Gastritis
}

National Cancer Institute

\section{Source}

National Cancer Institute. Viral Gastritis. NCI Thesaurus. Code C27184.

Inflammation of the stomach resulting from viral infection. 